\title{
ARTIKELEN
}

\section{Duidelijke taal: wat heb je eraan?}

\section{Over in voorlichting 'vertaalde' (belasting)wetgeving}

\section{T.A. Cramwinckel}

\section{Inleiding}

De afgelopen jaren is er veel wetenschappelijke en maatschappelijke aandacht voor de toegankelijkheid van het recht voor burgers. ${ }^{1}$ Het 'burgerperspectief' wint aan terrein. ${ }^{2}$ Belangrijk onderdeel daarvan is de aandacht voor begrijpelijk taalgebruik. In dit kader zijn diverse ontwikkelingen te signaleren, zoals het project 'Klare taal' en 'project Wieb' ('Wat ik eigenlijk bedoel') bij de rechterlijke macht. ${ }^{3}$ Overheidsbreed is er de recent opgerichte 'Direct Duidelijk Brigade', die ten doel heeft overheidsorganisaties duidelijker te laten communiceren met burgers. ${ }^{4} \mathrm{Wat}$ deze initiatieven gemeen hebben, is dat zij juridische taal beogen te transformeren naar voor burgers toegankelijke(re) taal. Een terrein bij uitstek waarin - zoals het themanummer luidt - 'voorbij het juridisch taalgebruik' wordt gegaan, betreft communicatie van de Belastingdienst met burgers. In het bijzonder speelt dit bij algemene voorlichting, aangezien de Belastingdienst hierbij voor de uitdagende taak staat vaak zeer complexe belastingwetgeving ${ }^{5}$ te 'vertalen' naar begrijpelijke taal voor grote aantallen (fiscaal niet-deskundige) burgers. ${ }^{6}$ Deze invalshoek staat in deze bijdrage centraal.

1 Zie bijv. het themanummer 'Recht en taal' in Ars Aequi (zomer 2015) en ter illustratie het nieuwsoverzicht op www.bureautaal.nl over begrijpelijke (juridische) taal in o.a. medische bijsluiters, taal van de notaris, digitale overheidsformulieren, werk- en veiligheidsinstructies, cao's, wetgeving en polisvoorwaarden.

2 Zie bijv. op wetgevingsniveau het advies van de Raad van State bij het Belastingplan 2019, Kamerstukken II 2018/19, 35026, nr. 4, p. 2, 7 en 13, en in de rechtspraak: ABRvS 29 mei 2019, ECLI:NL:RVS:2019:1694, AB 2019/302.

3 Zie bijv. www.rechtspraak.nl/Organisatie-en-contact/Organisatie/Raad-voor-de-rechtspraak/ Nieuws/Paginas/De-uitspraak-20-de-rechtspraak-en-klare-taal.aspx.

4 Zie https://directduidelijk.nl/nieuws/staatssecretaris-knops-extra-mensen-en-middelen-voorbegrijpelijke-taal (geraadpleegd op 19 december 2019).

5 Belastingwetgeving respectievelijk belastingwetgever vat ik hier ruim op als fiscale wet- en regelgeving respectievelijk fiscale regelgever.

6 Vgl. M.F. Steehouder \& C.J.M. Jansen, Taalverkeersproblemen tussen overheid en burger. Een onderzoek naar verbeteringsmogelijkheden van voorlichtingsteksten en formulieren, Den Haag: Sdu Uitgevers 1989, p. 16, over de 'vertaalslag' die schrijvers van voorlichtingsteksten moeten leveren om formeel-juridische wetteksten begrijpelijk te maken voor de burger. Met 'vertalingen' doel ik op voorlichting (niet bijv. belastingaanslagen, toezeggingen, beleid of rulings). 
Over het belang van begrijpelijke taal bestaat consensus. ${ }^{7}$ Wat echter in de (fiscale) wetenschappelijke discussies over dit thema relatief onderbelicht blijft, zijn de juridische implicaties van begrijpelijke 'vertalingen'. ${ }^{8}$ Het doel van deze bijdrage is om - vanuit het belastingrecht - stil te staan bij een aantal vragen die zich voordoen bij de vertaalslag van belastingwetgeving naar begrijpelijke taal bij voorlichting. Belangrijke vraag is dan: wat is de fiscaal-juridische status van voorlichting? Relevant zijn ook vragen als: Welke 'ingrepen' zijn nodig in de vertaling? Is begrijpelijke taal alleen maar 'goed', of zijn er ook nadelen? Kunnen burgers rechten ontlenen aan 'vertaalde' belastingwetgeving? En wat betekent dat voor de belastingwetgever? Om bovenstaande (normatief-juridische) vragen te beantwoorden, onderzoek ik (communicatie)beleid van de Belastingdienst, (fiscale) literatuur en (fiscale) jurisprudentie met betrekking tot voorlichting van de Belastingdienst aan burgers. De focus van deze bijdrage is dus niet zozeer hoe de Belastingdienst 'betere' voorlichting kan geven of hoe de belastingwetgever 'betere' wetten kan maken, maar ziet op juridische consequenties van het gegeven dát de Belastingdienst wetgeving vertaalt. Tot slot merk ik op dat ik mij in deze bijdrage richt op het belastingrecht, maar dat goed denkbaar is dat genoemde vragen in zijn algemeenheid relevant zijn in gevallen waarin juridische taal wordt omgezet in begrijpelijke taal.

Deze bijdrage gaat achtereenvolgens in op de 'vertaalpraktijk' van de Belastingdienst (par. 2), voor- en nadelen van begrijpelijke vertalingen (par. 3) en de fiscale rechtsbescherming van burgers wanneer zij vertrouwen op voorlichting (par. 4). Daarna volgt een blik op de wetgever (par. 5) en tot slot een conclusie (par.6).

\section{De Belastingdienst als 'vertaler' in voorlichting}

De Belastingdienst staat als uitvoeringsinstantie tussen enerzijds de belastingwetgever en anderzijds degenen tot wie belastingwetten zich richten (zoals burgers), terwijl laatstgenoemden lang niet altijd 'dezelfde taal' spreken. ${ }^{9}$ Wat bete-

7 Variërend van het belang van begrijpelijke taal in wetgeving (zie R.L.G. van den Heuvel, Duidelijkheid van fiscale wetgeving. Een onderzoek naar een nadere invulling van de kwaliteitseis van eenvoud, duidelijkheid en toegankelijkheid van fiscale wetgeving (diss. Leiden), 2018) en voorlichting (bijv. Steehouder \& Jansen 1989) tot begrijpelijke rechterlijke uitspraken (bijv. Kamerstukken II 2018/19, 35000 VI, nr. 58).

8 Dit thema is onderwerp van mijn lopende promotieonderzoek. Eerder heb ik dit geadresseerd in bijv. T.A. Cramwinckel, 'De Belastingdienst als vertaler: van wettekst naar webtekst. Een casestudy’, MBB 2014, afl. 7/8, p. 299-312. Zie ook R.H. Happé, Drie beginselen van fiscale rechtsbescherming (diss. Leiden), Deventer: Kluwer 1996. Op het terrein van het staats- en bestuursrecht zie S.A.L. van de Sande, Overheidsaansprakelijkheid voor het verstrekken van onjuiste informatie (diss. Nijmegen), Deventer: Wolters Kluwer 2019.

9 Vgl. H.Th.J.F. van Maarseveen, 'Ten geleide', in: D.A. Donker \& P.J. van den Hoven, Recht spreken krom schrijven, Deventer: Kluwer 1983, p. 2: 'Rechtstaal wordt gemaakt door juristen voor de mensen: dezen ontvangen via de rechtstaal informaties en directieven. Niet dat zij rechtstaal begrijpen, zij hebben dikwijls vertalers nodig, maar de rechtstaal is op hen gericht.' 
kent dat voor de uitvoering, het communicatiebeleid en de balans tussen juridische juistheid en begrijpelijkheid bij de Belastingdienst? ${ }^{10}$

\subsection{De Belastingdienst als belastingheffer en dienstverlener}

Kenmerkend voor het belastingrecht is onder andere de massaliteit (bijvoorbeeld in 2018 had de Belastingdienst te maken met 8,5 miljoen particulieren, 5,6 miljoen toeslaggerechtigden, 9 miljoen aangiften en 5,4 miljoen telefoontjes van burgers ${ }^{11}$ ), de 'gedwongen winkelnering' (er is maar één Belastingdienst en vrijwel elke burger krijgt onontkoombaar en regelmatig te maken met belastingen) en de 'administratieve last' voor burgers in de vorm van het verstrekken van persoonlijke gegevens aan de Belastingdienst (denk alleen al aan de jaarlijkse belastingaangifte inkomstenbelasting, ${ }^{12}$ waarbij burgers ook bij een vooraf ingevulde aangifte zelf hun gegevens dienen te controleren en zo nodig aan te vullen). Kenmerkend is bovendien de complexiteit van het fiscale stelsel (belastingwetgeving is bijvoorbeeld omvangrijk, veranderlijk en kent een zeer technisch karakter ${ }^{13}$ ) en de wederzijdse afhankelijkheid tussen de Belastingdienst en burgers (vanwege bijvoorbeeld de massaliteit, de complexiteit en de informatiebehoefte over en weer).

Tegen deze achtergrond vervult de Belastingdienst zijn kerntaken, te weten het heffen en innen van rijksbelastingen en het uitkeren van toeslagen. ${ }^{14}$ Daarbij heeft de Belastingdienst als strategische doelstelling dat belastingplichtigen bereid zijn uit zichzelf (fiscale) regels na te leven, zonder dwingende en kostbare acties van de Belastingdienst ('compliance'). ${ }^{15}$ Belangrijk instrument is dienstverlening, zoals in de vorm van voorlichting via de website, toelichtingen bij het aan-

10 In deze bijdrage neem ik als gezegd als uitgangspunt dát de Belastingdienst wetgeving vertaalt (uitvoeringsniveau). Uiteraard is een belangrijke vraag (wetgevingsniveau), die ik niet bespreek (zie par. 5), of wetgeving zelf niet duidelijker en toegankelijker zou moeten zijn voor burgers, en hoe de wetgever dit kan bevorderen (zie Van den Heuvel 2018). Overigens zal de Belastingdienst - hoe goed de belastingwetgever ook zijn werk doet - altijd een vertaalslag moeten blijven maken (vgl. Van den Heuvel 2018, p. 230: 'Duidelijkheid inzake fiscale wetgeving kan daarom ook worden beschouwd als een gezamenlijke taal van de overheid (wetgever én de Belastingdienst) en haar onderdanen').

11 Belastingdienst Jaarplan 2020, p. 21.

12 Volgens H.M. Roose, Heffingsmethoden, een valse dichotomie (diss. Tilburg), 2019, p. 39 zijn er voor de inkomstenbelasting zo'n 400 aangifterubrieken.

13 Illustratief bijv. president Knot van De Nederlandsche Bank, die het belastingstelsel te complex acht (nieuwsbericht 20 november 2019 via www.nu.nl/economie/6012357/dnb-presidentbelastingstelsel-is-te-ingewikkeld-en-onevenwichtig.html), en een interview met voorzitter Zoetmulder van de Nederlandse Orde van Belastingadviseurs 'Zelfs expert snapt het niet meer: "Belasting moet veel simpeler" in De Telegraaf van 23 november 2018 (www.telegraaf.nl/ financieel/2832770/zelfs-expert-snapt-het-niet-meer-belasting-moet-veel-simpeler, geraadpleegd op 3 januari 2020).

14 Handhavingsbrief Belastingdienst 2018, bijlage 1, biedt een overzicht van de taken van de Belastingdienst.

15 Recent in Jaarplan Belastingdienst 2020, p. 6-7. 
gifteprogramma, BelastingTelefoon, brochures en sociale media. ${ }^{16}$ Met goede voorlichting wil de Belastingdienst het burgers zo gemakkelijk mogelijk maken om hun verplichtingen na te komen, hun rechten geldend te maken en fouten te voorkomen (in plaats van correcties achteraf). ${ }^{17}$ De Belastingdienst stelt zich aldus (ook) nadrukkelijk op als dienstverlener. Bovendien vormt dit onderdeel van de 'voorlichtende taak' van de Belastingdienst. ${ }^{18}$

\subsection{Communicatiebeleid Belastingdienst ('Duidelijke taal is normaal')}

De Belastingdienst is een early adopter van begrijpelijke taal. Al in de jaren tachtig werden neerlandici en communicatiedeskundigen ingeschakeld om het aangiftebiljet, formulieren en toelichtingen toegankelijker te maken. ${ }^{19}$ Er volgde een huisstijl en communicatierichtlijnen. ${ }^{20}$ Het communicatiebeleid van de Belastingdienst functioneert onder de noemer 'Duidelijke taal is normaal'. ${ }^{21}$ Daarbij neemt de Belastingdienst drie algemene uitgangspunten in acht: communicatie is (1) lezersgericht, (2) sturend (gericht op gedrag en compliance) en (3) doelgroepgericht (bijvoorbeeld particulieren, ondernemers, grote bedrijven).

Wat betekent het communicatiebeleid voor de wijze waarop de Belastingdienst (juridische taal uit) fiscale wet- en regelgeving vertaalt naar begrijpelijke voorlichting voor burgers? Duidelijk is dat het vertaalproces een samenspel is tussen (fiscaal) inhoudelijke specialisten en tekstredacteuren. ${ }^{22}$ Bovendien kan uit het communicatiebeleid worden afgeleid hoe de Belastingdienst met burgers wil communiceren (zoals met voorlichting) en wat voor een soort tekstuele ingrepen daarbij (moeten) worden gemaakt. ${ }^{23}$ Ik licht dat hieronder toe (par. 2.3), gevolgd door een concreet voorbeeld van een 'vertaling' van de Belastingdienst (par. 2.4).

\subsection{Juridische juistheid en begrijpelijkheid}

Voorlichting moet, zo volgt uit de 'Communicatierichtlijnen voor Belastingdienstteksten', zowel juridisch juist als begrijpelijk zijn:

16 Bijv. in Beleidsdoorlichting Dienstverlening Belastingdienst 2015, p. 7. Bij het onderdeel Klantinteractie \& Services van de Belastingdienst werkt $1000 \mathrm{fte}$, bij overige interne processen - waar het Centrum voor Kennis en Communicatie onderdeel van is - in totaal $5800 \mathrm{fte}$ (Handhavingsbrief 2018, p. 7).

17 O.a. Handhavingsstrategie Belastingdienst 2017, p. 7.

18 Zie reeds in HR 26 september 1979, nr. 19.250ECLI:NL:HR:1979:AM4918, BNB 1979/311.

19 T. Pfeil, Op gelijke voet, de geschiedenis van de Belastingdienst, Deventer: Kluwer 2009, p. 404-405.

20 Zie bijv. diverse richtlijnen over het communicatiebeleid van de Belastingdienst, te raadplegen via www.rijkshuisstijl.nl > organisatiespecifieke richtlijnen > Belastingdienst > taalgebruik Belastingdienst.

21 Belastingdienst, Taal- en tekstafspraken Belastingdienst (kenmerk 20140826), onderdeel 'Communicatierichtlijnen voor Belastingdienstteksten’, p. 4 (te raadplegen via www.rijkshuisstijl.nl).

22 Zie www.rijkshuisstijl.nl > Organisatiespecifieke richtlijnen > Belastingdienst > Taalgebruik Belastingdienst > Huisstijl taal Belastingdienst > Schrijfwijze woorden en begrippen.

23 Communicatiebeleid van de Belastingdienst geeft ook inzicht in andere aspecten rondom voorlichting, bijv. op welk moment voorlichting wordt gegeven en via welk kanaal. Deze (niet-talige) aspecten laat ik onbesproken. 
'[Z]org voor een goede balans tussen juridische juistheid en begrijpelijkheid We willen teksten die fiscaal juist zijn én in duidelijke taal geformuleerd. Het één hoeft niet ten koste te gaan van het ander. ${ }^{24}$

Begrijpelijkheid betekent niet jip-en-janneketaal, maar toegankelijk taalgebruik voor de doelgroep (zoals burgers met weinig fiscale kennis). Dat vraagt van de Belastingdienst dus inspanningen op tekst-, zin- en woordniveau.

Voor de tekst als geheel geldt dat deze logisch gestructureerd moet zijn en een 'scannable layout' moet bevatten. ${ }^{25}$ Korte alinea's, tussenkopjes en opsommingen dragen hieraan bij. Op zinsniveau wordt begrijpelijkheid bereikt door zinnen met een eenvoudige structuur (geen tangconstructies of opeenstapelingen van bijzinnen), korte zinnen, positieve formuleringen (geen dubbele ontkenningen) en geen vaag taalgebruik (geen onpersoonlijke lijdende vorm). ${ }^{26}$ Ook dienen formuleringen slechts voor één uitleg vatbaar te zijn (dubbelzinnigheid vermijden). Op woordniveau geldt dat jargon moet worden vermeden, evenals afkortingen en moeilijke woorden. ${ }^{27}$

Uiteraard kan de Belastingdienst niet om fiscale en juridische terminologie heen. Fiscale wetgeving - uitgangspunt voor de Belastingdienst - kent immers technische begrippen en fiscale concepten. De lastigheid bij dergelijke concepten - zeker gezien de technische aard van het belastingrecht - is dat zij doorgaans geen referent in de gewone taal kennen (bijvoorbeeld technische begrippen als 'meesleepregeling', 'aanmerkelijk belang' en 'navorderingsaanslag'). Ook kan de fiscale betekenis afwijken van de 'gewone' betekenis (bijvoorbeeld 'partner', 'ondernemer' en 'fout'). Hoe gaat de Belastingdienst hiermee om? Het ene uiterste is het weglaten van fiscale terminologie, het andere uiterste deze ongewijzigd overnemen. De Belastingdienst kiest voor de 'light variant' van laatstgenoemde optie. Technische begrippen worden gehandhaafd, maar - om begripsproblemen te voorkomen voorzien van een toelichting (al dan niet met voorbeelden). ${ }^{28}$

Ten aanzien van de eis van juridische juistheid kan uit de Communicatierichtlijnen worden afgeleid dat het erom gaat dat informatie 'inhoudelijk juist' moet zijn. ${ }^{29}$ Dat is niet nader gespecificeerd, maar ik veronderstel dat dit betekent dat het fiscaal-juridisch correct moet zijn, dus in lijn met geldende fiscale wet- en

Taal- en tekstafspraken Belastingdienst, onderdeel 'Communicatierichtlijnen voor Belastingdienstteksten', p. 4.

25 Taal- en tekstafspraken Belastingdienst, onderdeel 'Structuur', p. 6.

26 Taal- en tekstafspraken Belastingdienst, onderdeel 'Formulering', p. 6-8.

27 De Huisstijlwijzer-'checklist' geeft hierbij houvast, zie www.rijkshuisstijl.nl/organisatie specifieke-richtlijnen/belastingdienst/taalgebruik-belastingdienst/checklist-taal (geraadpleegd op 19 december 2019).

28 Rijkshuisstijl > Organisatiespecifieke richtlijnen > Belastingdienst > Taalgebruik Belastingdienst $>$ Formulering en Toon $>$ Terminologie en jargon.

29 Rijkshuisstijl > Organisatiespecifieke richtlijnen > Belastingdienst > Taalgebruik Belastingdienst $>$ Inhoud taalgebruik Belastingdienst. 
regelgeving en jurisprudentie. ${ }^{30}$ Een interessante vraag is hoe juridische juistheid zich verhoudt tot volledigheid. Beschrijft de Belastingdienst slechts de hoofdregel of ook details, en wat te doen met uitzonderingen en uitzonderingen op uitzonderingen? Uitgangspunt is dat de Belastingdienst 'snel toegankelijke informatie op hoofdlijnen' geeft, kort, bondig en puntsgewijs. ${ }^{31}$ De informatie moet 'precies voldoende' zijn, aldus de Taal- en tekstafspraken. ${ }^{32}$ Hoeveel informatie dat is, hangt af van de situatie.

Opvallend is tot slot dat de Belastingdienst in zijn communicatie zo min mogelijk naar wetsartikelen verwijst. ${ }^{33}$ In plaats daarvan wil de Belastingdienst uitleggen wat de wet praktisch voor iemand betekent. Verder bevat voorlichting, zoals via de website, bij mijn weten niet standaard een disclaimer.

\subsection{Een voorbeeld van een vertaling: 'eigen woning'}

Ter illustratie van de vertaalslag die de Belastingdienst maakt, bespreek ik hieronder beknopt een voorbeeld van enerzijds een wettekst en anderzijds de begrijpelijke vertaling in de vorm van voorlichting op de website van de Belastingdienst. Als voorbeeld neem ik de wettelijke definitie van de 'eigen woning'. Deze bepaling is voor veel burgers relevant (denk aan de hypotheekrenteaftrek voor eigenwoningbezitters), terwijl de regels die daarop betrekking hebben (de 'eigenwoningregeling') als zeer complex worden beschouwd ${ }^{34}$ en op dit punt regelmatig fouten in de aangifte worden gemaakt. ${ }^{35}$

Wat is een 'eigen woning'? De definitie in artikel 3.111 van de Wet inkomstenbelasting 2001 luidt:

\section{'Artikel 3.111. Eigen woning}

1 In deze afdeling en de daarop berustende bepalingen wordt verstaan onder eigen woning: een gebouw, een duurzaam aan een plaats gebonden schip of woonwagen als bedoeld in artikel 1, onder l, van de Wet op de

30 Vgl. Belastingdienst, Beleidsplan Diensten en Communicatie 1995-1999, 1994, p. 12: 'De fiscaaljuridische inhoud van elk communicatiemiddel moet juist en ondubbelzinnig zijn; de communicatiemiddelen zijn samen fiscaal-juridisch volledig. Maar tegelijkertijd moeten de fiscaal-juridische aspecten voor de belastingplichtigen duidelijk zijn. Een tekst moet begrijpelijk zijn. De kwaliteit en effectiviteit van de informatiedragers is pas voldoende als ze inhoudelijk fiscaal-juridische [sic] juist, ondubbelzinnig èn begrijpelijk zijn.'

31 Taal- en tekstafspraken Belastingdienst, onderdeel 'Communicatierichtlijnen voor Belastingdienstteksten', p. 4.

32 Taal- en tekstafspraken Belastingdienst, onderdeel 'Eenvoudig en duidelijk communiceren', p. 8.

33 Taal- en tekstafspraken Belastingdienst, par. 6.4.1 en onderdeel 'Communicatierichtlijnen voor Belastingdienstteksten', p. 4. Een interessante vraag is hoe deze keuze van de Belastingdienst zich verhoudt tot andere overheidsorganisaties/uitvoerders van wetgeving.

34 De eigenwoningregeling is volgens een evaluatie van onderzoeksbureau Panteia te complex en daardoor niet goed houdbaar, controleerbaar, uitvoerbaar en handhaafbaar, zie brief van de Staatssecretaris van Financiën over de evaluaties van de eigenwoningregeling van 13 december 2019, kenmerk 2019-0000214241.

35 Zie bijv. brief van de Staatssecretaris van Financiën van 28 februari 2018, kenmerk 2018-0000028557. 
huurtoeslag, of een gedeelte van een gebouw, een schip of een woonwagen, met de daartoe behorende aanhorigheden, voorzover dat de belastingplichtige of personen die behoren tot zijn huishouden anders dan tijdelijk als hoofdverblijf ter beschikking staat op grond van:

a eigendom, waaronder begrepen economische eigendom, of een recht van lidmaatschap van een coöperatie, indien met betrekking tot die woning de belastingplichtige of zijn partner de voordelen geniet, de kosten en lasten op de belastingplichtige of zijn partner drukken en de waardeverandering de belastingplichtige of zijn partner grotendeels aangaat;

b een recht van vruchtgebruik, een recht van bewoning of een recht van gebruik dat de belastingplichtige krachtens erfrecht heeft verkregen, indien met betrekking tot die woning de belastingplichtige de voordelen geniet en de kosten en lasten op hem drukken.

2 Een woning wordt voor de periode dat deze in het kalenderjaar leeg staat mede aangemerkt als eigen woning indien de woning de belastingplichtige in het kalenderjaar of in een van de voorafgaande drie jaren als eigen woning als bedoeld in het eerste lid ter beschikking heeft gestaan en hij aannemelijk maakt dat de woning bestemd is voor verkoop. Indien een in de eerste volzin bedoelde woning vanaf enig moment in de daar bedoelde periode inkomen uit sparen en beleggen genereert en vervolgens vanaf enig moment weer belastbare inkomsten uit eigen woning, wordt een en ander voor de toepassing van artikel 3.119aa niet aangemerkt als een vervreemding, onderscheidenlijk als een verwerving. Voorts vindt artikel 2.14, derde lid, onderdelen b en c, met betrekking tot deze woning gedurende de in de eerste volzin bedoelde periode geen toepassing en wordt de woning ook gedurende deze periode voor de toepassing van de artikelen 10bis.4 en 10bis.5 aangemerkt als eigen woning.

3 Een woning wordt mede aangemerkt als eigen woning indien de belastingplichtige aannemelijk maakt dat de woning leeg staat of in aanbouw is en uitsluitend bestemd is om in het kalenderjaar of in een van de daaropvolgende drie jaren hem als eigen woning als bedoeld in het eerste lid ter beschikking te staan. Voor de toepassing van de eerste volzin wordt onder een woning in aanbouw mede verstaan een bouwkavel ter zake waarvan concrete stappen zijn gezet voor het in gang zetten van bouwkundige werkzaamheden voor de realisatie van een eigen woning. Ingeval de bouwkundige werkzaamheden zijn gestart, wordt voor de toepassing van de tweede volzin aangenomen dat de concrete stappen, bedoeld in die volzin, in ieder geval zes maanden voor de start van de bouwkundige werkzaamheden zijn gezet.

4 Een woning wordt voor ten hoogste twee jaren na het tijdstip waarop de woning de belastingplichtige niet langer anders dan tijdelijk als hoofdverblijf ter beschikking staat mede aangemerkt als eigen woning indien de belastingplichtige aannemelijk maakt dat gedurende die periode de woning zijn gewezen partner anders dan tijdelijk als hoofdverblijf ter beschikking staat. Voor de toepassing van dit lid en van het achtste lid 
wordt onder de gewezen partner mede verstaan de duurzaam gescheiden levende echtgenoot.

5 Een woning wordt voor ten hoogste twee jaren na het tijdstip waarop de woning de belastingplichtige niet langer anders dan tijdelijk als hoofdverblijf ter beschikking staat mede aangemerkt als eigen woning indien de belastingplichtige gedurende die periode is opgenomen in een verpleegof verzorgingshuis vanwege medische redenen of ouderdom.

6 Een woning die de belastingplichtige gedurende tenminste een jaar als eigen woning als bedoeld in het eerste lid ter beschikking heeft gestaan en sindsdien tijdelijk als hoofdverblijf niet anders dan tijdelijk ter beschikking staat, kan op verzoek mede worden aangemerkt als eigen woning indien gedurende die periode:

a de woning niet aan derden ter beschikking wordt gesteld en

$\mathrm{b}$ de belastingplichtige tezamen met zijn partner niet met betrekking tot een andere woning belastbare inkomsten uit eigen woning geniet.

7 Het tijdelijk ter beschikking stellen van een woning aan derden, ontneemt daaraan niet het karakter van hoofdverblijf.

8 Bij een belastingplichtige en zijn partner tezamen wordt niet meer dan één hoofdverblijf in aanmerking genomen. Indien partners meer dan één woning hebben die als hoofdverblijf kan worden aangemerkt, kunnen de belastingplichtige en zijn partner gezamenlijk bij de aangifte kiezen welke van die woningen als zodanig wordt aangemerkt.

9 Indien de belastingplichtige en zijn partner voor een kalenderjaar:

a de keuze om één woning als hoofdverblijf aan te merken hebben gemaakt, kan niet op die keuze worden teruggekomen;

b geen keuze hebben gemaakt, wordt geen van de woningen als hoofdverblijf aangemerkt.

10 Onder eigen woning wordt niet begrepen een naar verkeersopvatting zelfstandig gedeelte van een gebouw, schip of woonwagen met de daartoe behorende aanhorigheden dat wordt gebruikt:

1 in een onderneming van de belastingplichtige of persoon die tot zijn huishouden behoort en bij de bepaling van de winst van die onderneming ter zake van dat gebruik een bedrag ten laste van de winst kan worden gebracht;

2 voor resultaat uit een of meer werkzaamheden van de belastingplichtige of persoon die tot zijn huishouden behoort en bij de bepaling van dat resultaat ter zake van dat gebruik een bedrag ten laste van het resultaat kan worden gebracht, of

3 in een vennootschap waarin de belastingplichtige of persoon die tot zijn huishouden behoort een aanmerkelijk belang heeft als bedoeld in hoofdstuk 4, uitgezonderd de artikelen 4.10 en 4.11, en bij de bepaling van de winst van die vennootschap ter zake van dat gebruik een bedrag ten laste van de winst kan worden gebracht. ${ }^{36}$ 
De Belastingdienst heeft deze wettelijke definitie van 'eigen woning' als volgt vertaald op zijn website:

\section{'Wat is een eigen woning?}

Uw woning geldt als eigen woning als u voldoet aan de volgende 2 voorwaarden:

- U, uw fiscale partner, of u beiden bent eigenaar van de woning.

- De woning is uw hoofdverblijf.

- Een huurwoning of een verhuurd pand is geen eigen woning.

\section{Een eigen woning is ook:}

- een woonboot met een vaste ligplaats

- en woonwagen met een vaste standplaats

- een woning waarvan u of uw fiscale partner het recht hebt van erfpacht voor de grond of het recht van opstal

- een woning op basis van een lidmaatschap van een coöperatieve flatvereniging

- een vakantiewoning

- een woning waarvan u of uw fiscale partner het vruchtgebruik, recht van bewoning of recht van gebruik hebt geërfd

- U moet hier dan wel zelf in wonen, en zelf de kosten en lasten ervan betalen.

\section{Wat hoort bij de eigen woning?}

Een schuur, garage of land kan ook bij de eigen woning horen. Gebruikt u de woning voor uw onderneming? Dan geldt mogelijk slechts een gedeelte als eigen woning.

\section{Maximaal 1 woning als hoofdverblijf}

U kunt maar 1 woning als hoofdverblijf hebben. Hebt u een fiscale partner? En hebt $\mathrm{u}$ allebei een eigen woning? Dan moet $\mathrm{u}$ kiezen welke woning $\mathrm{u}$ aanmerkt als de woning die uw hoofdverblijf is. Van die woning kunt u de rente aftrekken en telt $\mathrm{u}$ het eigenwoningforfait op bij de inkomsten. De waarde en de eventuele schuld van de andere woning hoort in uw aangifte bij box 3 (sparen en beleggen).

Let op!

In een aantal situaties kunt $\mathrm{u}$ wel (tijdelijk) meer woningen opgeven als eigen woning. Bijvoorbeeld als u uw oude woning nog niet hebt verkocht, of als $\mathrm{u}$ duurzaam gescheiden leeft. ${ }^{37}$ 
Wat valt op bij deze vertaling? Ik noem enkele in het oog springende zaken. ${ }^{38}$ In de eerste plaats valt het verschil in lengte op: waar het wetsartikel 927 woorden telt, is de 'vertaling' 277 woorden lang. Daarnaast zijn lange zinnen vervangen door korte zinnen, technische begrippen worden toegelicht (bijvoorbeeld het wettelijke begrip 'eigendom' via een hyperlink bij 'eigenaar', en de fiscale betekenis van 'eigen woning' wordt gespecificeerd ten aanzien van de gebruikelijke betekenis van het begrip 'woning') en fiscale concepten worden geconcretiseerd (zo worden uitbreidingen op het eigenwoningbegrip in lid $2 \mathrm{t} / \mathrm{m} 6$ voor bijzondere situaties worden onder de aandacht gebracht onder 'Let op!' en kopjes in het menu links). Ook valt op dat ten behoeve van de lezer de structuur van de vertaling anders is dan de wettekst (de volgorde van de informatie is bijvoorbeeld aangepast, er zijn koppen aangebracht, en er is een opzet met vragen en antwoorden gemaakt). Tot slot is te zien dat sommige zaken in deze vertaling zijn weggelaten (bijvoorbeeld de eigen woning gedurende een periode van (ver)bouw of bij opname in een verpleeg- of verzorgingshuis ${ }^{39}$ ) of juist zijn toegevoegd ten opzichte van de wettekst (bijvoorbeeld dat een 'vakantiehuis' soms ook als eigen woning kan kwalificeren), of zijn vereenvoudigd (bijvoorbeeld de wettelijke eis dat de eigen woning anders dan tijdelijk als hoofdverblijf ter beschikking staat op grond van (bijvoorbeeld) eigendom wordt geconcretiseerd c.q. vereenvoudigd in 'twee voorwaarden').

$\mathrm{Al}$ met al is duidelijk dat de Belastingdienst diverse tekstuele ingrepen toepast om belastingwetgeving op toegankelijke en begrijpelijke wijze aan burgers uit te leggen in voorlichting. De balans tussen juridische juistheid en begrijpelijkheid is daarbij voortdurend een uitdaging.

\section{Voor- en nadelen van vertaalde (belasting)wetgeving}

Dat de Belastingdienst in zijn communicatie met burgers 'voorbij juridisch taalgebruik' gaat, is onlosmakelijk onderdeel van zijn uitvoerings- en dienstverleningstaak. Maar begrijpelijke wetsuitleg kan ook in een normatief-juridisch licht worden geplaatst.

\subsection{Vertalen en simplexity}

Een belangrijke bijdrage aan de theorievorming over begrijpelijke communicatie met belastingplichtigen is geleverd door de Amerikaanse hoogleraren Blank en Osofsky. ${ }^{40} \mathrm{Zij}$ hebben het begrip simplexity in de fiscale, wetenschappelijke literatuur geïntroduceerd. Volgens Blank en Osofsky wordt toegankelijke uitleg van de

38 Voor een evaluatie van de kwaliteit van vertalingen van de Belastingdienst verwijs ik naar een eerdere casestudie in Cramwinckel 2014.

39 Maar zie ook andere pagina's, bijv. via www.belastingdienst.nl/wps/wcm/connect/bldcontentnl/ belastingdienst/prive/woning/tijdelijk_2_woningen/(geraadpleegd op 3 januari 2020).

40 J.D. Blank \& L. Osofsky, 'Simplexity: Plain Language and the Tax Law', Emory Law Journal (66) 2017/189, p. 189-264. 
belastingadministratie ${ }^{41}$ gekenmerkt door simplexity. Simplexity - een samentrekking van simplicity en complexity - doet zich voor wanneer de overheid een toegankelijke en begrijpelijke uitleg van wetgeving geeft, waarbij niet de aandacht op de onderliggende complexiteit wordt gevestigd en die complexiteit ook niet door wetswijzigingen verdwijnt. ${ }^{42}$ Anders dan bij simplicity (waarbij onderliggende belastingwetgeving wordt vereenvoudigd), maakt simplexity het belastingstelsel als zodanig niet eenvoudiger. ${ }^{43}$ Het leidt slechts tot ogenschijnlijke eenvoud.

Simplexity kan zich volgens Blank en Osofsky op verschillende manieren voordoen. ${ }^{44}$ Zo kan de belastingadministratie - ten behoeve van vereenvoudiging - belastingwetgeving in de uitleg presenteren als eenduidig en ondubbelzinnig, terwijl over de reikwijdte van een begrip of regeling wel degelijk discussie mogelijk is. ${ }^{45}$ Simplexity kan zich ook voordoen wanneer in de vertaalslag vereenvoudiging plaatsvindt door bijvoorbeeld het invullen van open normen, ${ }^{46}$ het vervangen van fiscaaltechnische begrippen door eenvoudigere terminologie ${ }^{47}$ of het geven van voorbeelden. ${ }^{48}$ Verder is sprake van simplexity indien de begrijpelijke uitleg niet volledig is.

Simplexity is op zichzelf beschouwd een neutraal concept, aldus Blank en Osofsky. Het is eenvoudigweg het resultaat van de afweging (trade off) van de eisen van juridische juistheid en begrijpelijkheid. Toch heeft simplexity wel degelijk een normatieve kant. Zo is begrijpelijke communicatie enerzijds wenselijk met het oog op een efficiënte uitvoering van de belastingwet. Anderzijds is er ook een keerzijde. Het effect van simplexity is dat de onderliggende complexiteit van belastingwetge-

41 Blank en Osofsky bespreken simplexity aan de hand van communicatie van de Amerikaanse belastingdienst (IRS). Waar ik hun ideeën bespreek, gebruik ik het neutrale (maar wat ouderwetse) 'belastingadministratie'. Toegepast op de Nederlandse context gebruik ik 'Belastingdienst'.

42 Blank \& Osofsky 2017, p. 193: 'As we define it, simplexity occurs when the government presents clear and simple explanations of the law without highlighting its underlying complexity or reducing this complexity through formal legal changes.'

43 Blank \& Osofsky 2017, p. 204.

44 Blank \& Osofsky 2017, p. 207-228.

45 Een voorbeeld biedt de rechtsvraag of tijdelijke verhuur van een gedeelte van de eigen woning is belast in box 1 van de inkomstenbelasting (zie hierover bijv. www.taxlive.nl/nl/documenten/ nieuws/airbnb-uitspraak-aangifteprogramma-belastingdienst-wordt-een-hele-hobbel/ en www. telegraaf.nl/financieel/2512655/snel-airbnb-inkomsten-tuinhuisje-wel-belast), geraadpleegd op 19 december 2019.

46 Bijv. art. 4 Algemene wet inzake rijksbelastingen bepaalt dat waar iemand woont, wordt beoordeeld 'naar de omstandigheden'. De Belastingdienst maakt dit concreet met omstandigheden die volgens de rechtspraak relevant zijn voor de beoordeling van de fiscale woonplaats (zie www. belastingdienst.nl/wps/wcm/connect/bldcontentnl/belastingdienst/zakelijk/internationaal/ vermogen/common_reporting_standard/regels, geraadpleegd op 17 december 2019).

47 De Belastingdienst vervangt bijv. het wettelijke begrip 'resultaat uit overige werkzaamheden' door 'inkomsten uit overig werk' (www.belastingdienst.nl/wps/wcm/connect/nl/werk-eninkomen/content/wat-zijn-inkomsten-uit-overig-werk, geraadpleegd op 19 december 2019).

48 Bijv. met voorbeelden van meer dan normaal vermogensbeheer in www.belastingdienst.nl/wps/ wcm/connect/bldcontentnl/belastingdienst/prive/werk_en_inkomen/werken/niet_in_loon dienst_werken/vermogensbeheer_waarvoor_u_meer_werkzaamheden_uitvoert_dan_normaal, geraadpleegd op 19 december 2019. 
ving voor belastingplichtigen verborgen blijft. ${ }^{49}$ Voortbouwend op Blank en Osofsky bespreek ik hierna beknopt enkele voor- en nadelen van simplexity in voorlichting van de Belastingdienst.

\subsection{Voordelen}

De vertaalslag die de Belastingdienst maakt in voorlichting heeft evident voordelen, zowel voor de Belastingdienst als voor burgers. ${ }^{50}$

\section{- Toegankelijkheid}

In de eerste plaats maken begrijpelijke vertalingen het belastingrecht toegankelijk voor burgers. ${ }^{51}$ Zonder vertaalslag van de Belastingdienst zouden burgers zelf het relevante recht moeten raadplegen. ${ }^{52}$ Naast wettelijke bepalingen kunnen daarbij ook aanverwante (lagere) regelgeving, beleid en jurisprudentie relevant zijn. Nog afgezien van de vraag of de gemiddelde burger dergelijke bronnen weet te vinden, is het maar de vraag of niet-deskundigen dergelijke informatie kunnen doorgronden en toepassen. ${ }^{53}$

\section{- Efficiëntere belastingheffing}

In de tweede plaats heeft voorlichting voordelen in de heffings- en inningssfeer. Waar Blank en Osofsky nadruk leggen op potentiële voordelen vanwege de mogelijkheid dat de belastingadministratie belastingplichten met haar wetsuitleg kan 'sturen' in een voor de overheid gunstige richting, ${ }^{54}$ is mijns inziens het belangrijkste (theoretische en praktische) voordeel dat begrijpelijke taal zowel direct als indirect kan bijdragen aan compliance. ${ }^{55}$ Enerzijds bevordert toegankelijke uitleg dat burgers hun fiscale verplichtingen (kunnen) kennen en minder fouten maken; anderzijds draagt een servicegerichte houding bij aan het imago van de fiscus en aan een positieve(re) houding van belastingplichtigen en meer vertrouwen in de fiscus. ${ }^{56}$

\section{- Inzicht in interpretatie Belastingdienst}

Tot slot kan begrijpelijke wetsuitleg burgers volgens Blank en Osofsky inzicht geven in de positie die de fiscus inneemt bij de interpretatie van de wet, bijvoorbeeld wanneer een regeling voor meerderlei uitleg vatbaar is of als de toepassing

49 Blank \& Osofsky 2017, p. 207.

50 Uitgebreider in Blank \& Osofsky 2017, p. 234-237.

51 Voorlichting kan mogelijk ook worden gebruikt voor de verbetering van de kwaliteit van wetgeving via terugkoppeling; ik kom daarop terug in par. 5.1.

52 Al dan niet via inschakeling van (betaalde) hulp, zoals een belastingadviseur.

53 Blank \& Osofsky 2017, p. 235: 'This shortcut can enable the taxpayer to complete his tax return more efficiently than if he consulted the Internal Revenue Code directly, assuming he could even access the text.' Vgl. L.J.A. Damen, 'Is de burger triple A: alert, argwanend, assertief of raakt hij lost in translation?', in: Vertrouwen in de overheid (VAR-reeks 160), Den Haag: Boom juridisch 2018, p. 24.

54 Blank \& Osofsky 2017, p. 236-237. Vgl. over beleid Van den Heuvel 2018, p. 66-67 en 223.

55 Bijv. Beleidsdoorlichting dienstverlening Belastingdienst 2011-2015, 2015, par. 2.

56 Blank \& Osofsky 2017, p. 237. 
ervan sterk contextafhankelijk is. ${ }^{57}$ Hoewel ik dat theoretisch met hen eens ben, maak ik als kanttekeningen dat (1) dit voordeel in de praktijk alleen zichtbaar is als burgers bekend zijn met de (onduidelijkheid van de) onderliggende wet, en (2) de geboden houvast beperkt is, namelijk alleen voor zover de Belastingdienst zich aan zijn wetsuitleg houdt of kan worden gehouden. ${ }^{58}$

\subsection{Nadelen}

De eliminatie van juridisch taalgebruik ten gunste van begrijpelijke taal heeft ook een keerzijde. ${ }^{59}$

\section{- Minder transparantie ten aanzien van de onderliggende belastingwet}

Een nadeel is dat met de vertaalslag de onderliggende complexiteit van fiscale wet- en regelgeving uit beeld verdwijnt. Blank en Osofsky wijzen op het paradoxale effect van begrijpelijke wetsuitleg, dat het risico bestaat dat burgers hierdoor juist minder kennis krijgen van het (onderliggende) belastingrecht. ${ }^{60} \mathrm{Zij}$ plaatsen dit probleem in de sfeer van 'tax transparency' ${ }^{61}$ en democratische waarden. Mijns inziens is het probleem niet zozeer dat de onderliggende complexiteit naar de achtergrond verdwijnt, maar (1) dat hierbij juridische elementen verloren kunnen gaan, ${ }^{62}$ en (2) dat burgers zich lang niet altijd bewust zijn van het feit dát sprake is van een vertaalslag tussen wetgeving en begrijpelijke voorlichting. ${ }^{63}$ Daarbij merk ik op dat in het geval dat de vertaling van de Belastingdienst geen juridische status heeft (zie par. 4) en de verwachtingen hierover niet goed worden gemanaged, burgers op het verkeerde been kunnen worden gezet.

\section{- Ongelijkheid tussen belastingplichtigen}

Een ander potentieel nadeel doet zich voor in de sfeer van gelijkheid tussen belastingplichtigen. Blank en Osofsky betogen dat de belastingadministratie bij de vertaling van wetgeving invloed kan hebben op de door burgers gepercipieerde uitleg van het belastingrecht. ${ }^{64}$ Een opvallende signalering van Blank en Osofsky is dat zowel sophisticated als unsophisticated taxpayers een voor hen gunstige uitleg ${ }^{65} \mathrm{zul}$ len volgen, maar dat effectief slechts sophisticated taxpayers de mogelijkheid heb-

57 Blank \& Osofsky 2017, p. 235-236.

58 Zie par. 2.3 en 4.2 .

59 Blank \& Osofsky 2017, p. 237-250.

60 Blank \& Osofsky 2017, p. 240.

61 Blank \& Osofsky 2017, p. 237-238. Onder tax transparency verstaan zij 'the government's openness to the public regarding its tax rules, agency interpretations, decision making processes, and enforcement practices'.

62 Zie par. 4.1.

63 Bijv. wanneer verwijzingen naar onderliggende wetgeving ontbreken, zie Blank \& Osofsky 2017, p. 242 en 249.

64 Blank \& Osofsky 2017, p. 204: 'In any event the mandate to describe the tax law using plain language provides the IRS with a unique and influential ability to shape taxpayers' and tax practitioners' perceptions and understanding of the tax law.'

65 Bijv. voorlichting over een gunstige toedeling van inkomen tussen fiscale partners, zie Rb. Zeeland-West-Brabant 29 november 2019, ECLI:NL:RBZWB:2019:5310. 
ben nadelige uitleg ${ }^{66}$ te identificeren en te betwisten (vanwege hun kennis van de belastingwet). In dat geval bestaat voor (niet-deskundige) burgers mogelijk een nadeel.

\section{- Rechtsbescherming}

Tot slot is een belangrijke vraag of het belastingrecht burgers voldoende rechtsbescherming biedt wanneer zij zich bij de afhandeling van hun fiscale verplichtingen laten leiden door vertalingen van de belastingadministratie. ${ }^{67}$ Deze vraag doet zich concreet voor als een burger verwachtingen ontleent aan voorlichting, terwijl in de vertaalslag juridische elementen verloren zijn gegaan (en de Belastingdienst bij het opleggen van de belastingaanslag niet handelt conform de verstrekte voorlichting maar terugvalt op de wet). Als burgers onvoldoende mogelijkheden hebben zich hiertegen te verzetten, is dat een principieel nadeel van begrijpelijke vertalingen van belastingwetgeving. Ik kom hierop terug in paragraaf 4 .

\section{- Weging voor-en nadelen}

Een belangrijke evaluatieve vraag is vervolgens: hoe moeten deze voor- en nadelen worden gewogen? ${ }^{68}$ Mijns inziens is simplexity - met al zijn voors en tegens inherent verbonden aan de voorlichtende taak van de Belastingdienst. De vraag is dan ook niet zozeer of simplexity wenselijk is, maar in welke mate. Een hoge mate van simplexity leidt tot een begrijpelijke(re) versie van de belastingwet (wat de toegankelijkheid en uitvoerbaarheid ten goede komt), maar brengt tegelijkertijd onvermijdelijk een minder accurate weergave mee. Het optimale niveau van simplexity komt in feite dan ook neer op de zoektocht naar de optimale balans tussen het belang van begrijpelijkheid en van juridische juistheid. Waar dat optimum ligt, is - zo betogen Blank en Osofsky terecht - niet in algemene zin te zeggen. ${ }^{69}$ Dat hangt af van (1) de waarde die aan beide belangen wordt toegekend en (2) of daaraan in een concreet geval voldoende recht wordt gedaan. Het grote belang dat de Belastingdienst én burgers toekennen aan begrijpelijke vertalingen (zie hierboven) is een belangrijk argument om in zijn algemeenheid te betogen dat de voordelen van simplexity zwaarder dienen te wegen dan de nadelen (en dat voorlichting dus wenselijk is). Uiteraard is het wel zaak om na te gaan hoe de nadelen zo veel mogelijk kunnen worden beperkt (bijvoorbeeld: Hoe kan de Belastingdienst (nog) betere voorlichting geven? Hoe kunnen de verwachtingen van burgers (beter) worden 'gemanaged'? ${ }^{70}$ ). Dat geldt bij uitstek in het belastingrecht, gezien de massaliteit van de uitvoering, de complexiteit van het belastingrecht, de afhankelijkheid van burgers van voorlichting en het belang dat de Belastingdienst daarbij heeft in het kader van de dienstverleningsstrategie. de Nationale ombudsman (rapport 2015/061) onterecht de indruk wekt dat het altijd voordelig is snel een voorlopige aanslag te vragen.

67 Vgl. Blank \& Osofsky 2017, p. 245-249.

68 Blank \& Osofsky 2017, p. 234.

69 Blank \& Osofsky 2017, p. 250-251.

70 Blank \& Osofsky 2017, p. 251-259. 


\section{Juridische status van 'vertalingen' en rechtsbescherming}

Belangrijke vraag is hoe het is gesteld met de (fiscale) rechtsbescherming van burgers die zich laten leiden door vertalingen van de Belastingdienst. Daarbij is enerzijds van belang welke tekortkomingen in de vertaalslag ('vertaalfouten') zich kunnen voordoen en anderzijds wie daarvan het (fiscale) risico draagt.

\subsection{Wat kan er misgaan bij de vertaling van belastingwetgeving naar voorlichting?}

De Belastingdienst voert zijn voorlichtende taak in het algemeen succesvol uit. ${ }^{71}$ Jaarlijkse onderzoeken laten zien dat burgers veel gebruik maken van voorlichting. ${ }^{72}$ Bovendien wordt de dienstverlening van de Belastingdienst gemiddeld genomen ook goed gewaardeerd. ${ }^{73}$ Toch gaat er onvermijdelijk wel eens iets mis. ${ }^{74}$ Voorlichting is naar haar aard immers afwijkend van de belastingwet, zowel qua taalgebruik als qua volledigheid. Het is evident niet gemakkelijk om technische begrippen eenvoudig en tegelijkertijd juridisch waterdicht te formuleren. Om elk risico op vertaalfouten uit te sluiten, zou de wettekst ${ }^{75}$ letterlijk moeten worden weergegeven. Maar is dan wel voldoende sprake van de vereiste 'begrijpelijkheid'? ${ }^{76}$ Zoals Verheij terecht opmerkt: '(...) als de brochure of de website even precies moet zijn als de wet, worden zij even onleesbaar als de wet. ${ }^{, 77}$ Onleesbare voorlichting maakt het burgers niet 'makkelijker' om hun verplichtingen na te komen (en dat is nu juist wel beoogd). De Belastingdienst bevindt zich dus niet in een benijdenswaardige positie.

Er zijn verschillende 'vertaalfouten' denkbaar. Gerubriceerd naar het type ingreep bij een vertaalslag kan het bijvoorbeeld gaan om (a) onjuistheden: in de voorlichting staat een verkeerd tarief (bij het aangiftebiljet staat bijvoorbeeld een onjuiste tarieventabel vermeld), ${ }^{78}$ een onjuiste instructie (de wijze waarop van een bepaalde regeling gebruik kan worden gemaakt, wordt bijvoorbeeld verkeerd

71 Overigens is de laatste jaren veel kritiek op de kwaliteit van voorlichting via de BelastingTelefoon, zie hierover de jaarlijkse onderzoeken van de Consumentenbond (bijv. www.consumentenbond.nl/nieuws/2018/weer-onvoldoende-voor-belastingtelefoon, geraadpleegd op 19 december 2019).

72 Bijv. de BelastingTelefoon wordt jaarlijks zo'n 3 miljoen keer gebeld (Jaarplan 2019 Belastingdienst, p. 17). De website is in 2016 bijna 90 miljoen keer bezocht (19e halfjaarsrapportage Belastingdienst, p. 6).

73 Jaarlijks publiceert de Belastingdienst de Fiscale Monitor met dergelijke cijfers. Zo is 95\% van de websitebezoekers neutraal tot zeer tevreden. Dat geldt voor driekwart van de bellers met de BelastingTelefoon (https://over-ons.belastingdienst.nl/over-de-belastingdienst/hoe-ziet-neder land-de-belastingdienst/functioneren/, geraadpleegd op 19 december 2019).

74 Zo illustreert de rechtspraak. Zie ook Happé 1996, p. 164 en Cramwinckel 2014, par. 4.

75 Nog afgezien van parlementaire toelichting, rechtspraak, lagere fiscale regelgeving, enz.

76 Vgl. redactie Vakstudie Nieuws in V-N 2017/25.17, die opmerkt dat burgers 'op een begrijpelijke wijze' willen worden voorgelicht en dat voor het raadplegen van wetteksten andere bronnen beschikbaar zijn.

77 N. Verheij, 'Is het bestuursrecht te vertrouwen? Bespreking VAR-preadviezen "Het vertrouwensdilemma" en "Is de burger triple A: alert, argwanend, assertief of raakt hij lost in translation?", NTB 2018/24.

Bijv. Hof Amsterdam 30 mei 2008, ECLI:NL:GHAMS:2008:BD3062, NTFR 2008/1732. 
weergegeven ${ }^{79}$ ) of een foute verwijzing (bijvoorbeeld een verkeerd paginanummer, waardoor de verkeerde tabel wordt toegepast). ${ }^{80}$ Verder kan (b) minder juridisch taalgebruik ertoe leiden dat juridische nuances verloren gaan omwille van begrijpelijkheid, variërend van situaties waarin de gekozen bewoordingen onvoldoende precies zijn (bijvoorbeeld wanneer de bewoordingen te ruim gesteld zijn, waardoor iemands situatie buiten de beschreven informatie valt ${ }^{81}$ ) tot situaties waarin de bewoordingen onduidelijk zijn (bijvoorbeeld wanneer een formulering voor meerdere interpretaties vatbaar is, zoals in een zaak ${ }^{82}$ waarbij de Belastingdienst 'gelding hebben' van een bepaald tarief voor kampeerauto's bedoelde in de zin van 'toegepast worden', terwijl een burger dit begreep als 'van kracht zijn'). Ook kan (c) de vereenvoudigingsslag tot gevolg hebben dat de uitleg onvolledig is, bijvoorbeeld als een wettelijke voorwaarde ontbreekt (bijvoorbeeld als voor toepassing van de ouderschapsverlofkorting in de toelichting niet is vermeld dat er een leeftijdsgrens geldt voor het kind ${ }^{83}$ ), of wanneer bepaalde wettelijke details en uitzonderingen op de hoofdregel achterwege blijven (bijvoorbeeld een stroomschema dat uitgaat van de situatie dat inkomen in Nederland is belast en daarmee niet voorziet in de uitzonderingssituatie dat inkomen niet in Nederland is belast, terwijl de conclusie in dat geval anders zou moeten luiden ${ }^{84}$ ). De grenzen tussen de typen vertaalfouten laten zich overigens niet altijd even scherp trekken.

\subsection{Beoordelingskader rechtsbescherming bij voorlichting}

Problemen kunnen ontstaan als een burger in goed vertrouwen afgaat op de vertaling van de belastingwet, terwijl de Belastingdienst (bij een geconstateerde discrepantie tussen vertaling en wet) terugvalt op de wet en een hogere belastingaanslag oplegt dan de burger gegeven de vertaling had verwacht. In zo'n geval ontstaat spanning tussen enerzijds de voorlichtende taak van de Belastingdienst en anderzijds het vertrouwen dat burgers aan de in dat kader verstrekte begrijpelijke vertalingen ontlenen. ${ }^{85}$ Voor wie is dan het (fiscale) risico van dergelijke 'vertaalfouten'?

In het belastingrecht wordt het beoordelingskader voor de beantwoording van bovenstaande vraag gevormd door de algemene beginselen van behoorlijk bestuur, in het bijzonder het vertrouwensbeginsel. Het vertrouwensbeginsel

79 Bijv. Rb. Noord-Nederland 18 oktober 2016, ECLI:NL:RBNNE:2016:4589, V-N 2017/2.16.14 (BelastingTelefoon over toepassing overgangsregeling voor oldtimers).

80 Bijv. HR 9 maart 1988, ECLI:NL:HR:1988:ZC3780, BNB 1988/148 (onjuiste verwijzing in toelichting).

81 Bijv. Hof Amsterdam 14 april 2003, ECLI:NL:GHAMS:2003:AF9798 (toelichting ouderenkorting is te ruim voor specifieke situatie belanghebbende).

82 Bijv. Hof 's-Hertogenbosch 3 maart 2017, ECLI:NL:GHSHE:2017:875, V-N 2017/25.17 (dubbelzinnige bewoordingen op website).

83 Bijv. Hof Arnhem-Leeuwarden 6 oktober 2015, ECLI:NL:GHARL:2015:7487, V-N 2015/64.15.10 (onvolledige toelichting voorwaarden ouderschapsverlofkorting).

84 Bijv. HR 24 september 2010, ECLI:NL:PHR:2010:BM1206, BNB 2010/314 (stroomschema voorziet niet in specifieke situatie belanghebbende). 
houdt kort gezegd in dat gerechtvaardigde verwachtingen moeten worden beschermd. ${ }^{86}$

De Hoge Raad heeft in zijn 'fiscale voorlichtingsjurisprudentie' ${ }^{87}$ bepaald dat belastingplichtigen weliswaar verwachtingen kunnen ontlenen aan voorlichting, maar dat dit niet tot gevolg heeft dat een juiste wetstoepassing opzij wordt gezet. De Hoge Raad maakt hierbij een afweging tussen enerzijds het beginsel dat de wet moet worden toegepast (legaliteitsbeginsel), en anderzijds het beginsel dat gewekte verwachtingen dienen te worden gehonoreerd (vertrouwensbeginsel). Het legaliteitsbeginsel is volgens de Hoge Raad doorslaggevend. Slechts in uitzonderingsgevallen krijgt het vertrouwensbeginsel voorrang - en wordt de fiscus wél gehouden aan zijn voorlichting. Daarvoor is vereist dat (1) de belastingplichtige de onjuistheid redelijkerwijs niet had hoeven te beseffen en (2) hij, afgaande op de onjuiste informatie, schade heeft geleden naast de te betalen belasting (het dispositievereiste). Een blik op de fiscale jurisprudentie laat zien dat van deze uitzonderingsgevallen zelden sprake is. ${ }^{88}$

Uit de summiere toelichting van de Hoge Raad kan worden afgeleid dat de gedachte bij genoemde risicoverdeling is dat zowel de Belastingdienst als belastingplichtigen erbij gebaat zijn dat de Belastingdienst zijn voorlichtende taak zo ruim mogelijk en 'onbelemmerd' moet kunnen uitoefenen. Op basis van deze jurisprudentie - die nog steeds geldend is - heeft voorlichting dus geen juridische status.

In sommige gevallen komt de belastingrechter burgers enigszins tegemoet door toepassing van het zorgvuldigheidsbeginsel. ${ }^{89}$ Wanneer het bijvoorbeeld uitsluitend aan onjuiste voorlichting van de Belastingdienst is te wijten dat ten onrechte een belastingteruggave is verleend, staat het zorgvuldigheidsbeginsel in de weg aan het in rekening brengen van belastingrente. ${ }^{90}$ Op de juridische status van voorlichting heeft het zorgvuldigheidsbeginsel echter (vooralsnog) geen effect.

\subsection{Aanleiding voor herijking?}

Belangrijke vraag is of het huidige beoordelingskader burgers nog wel voldoende rechtsbescherming biedt. Eerder heb ik betoogd dat de huidige risicoverdeling

87 HR 26 september 1979, ECLI:NL:HR:1979:AM4918, BNB 1979/311 (individuele inlichtingen) en HR 9 maart 1988, ECLI:NL:HR:1988:ZC3780, BNB 1988/148 (algemene voorlichting). Recenter: HR 24 september 2010, ECLI:NL:PHR:2010:BM1206, BNB 2010/314.

88 Zie bijv. geen gerechtvaardigd vertrouwen in HR 24 september 2010, ECLI:NL:HR: 2010:BM1206, BNB 2010/314 en HR 7 december 2001, ECLI:NL:HR:2001:AD6782, BNB 2002/45, en in de lagere rechtspraak bijv. Hof Amsterdam 2 juli 2019, ECLI:NL:GHAMS: 2019:2248 en Rb. Zeeland-West-Brabant 27 augustus 2015, ECLI:NL:RBZWB:2015:5628, V-N 2015/55.11. Een uitzondering (wel gerechtvaardigd vertrouwen) biedt bijv. Hof 's-Hertogenbosch 3 maart 2017, ECLI:NL:GHSHE:2017:875, V-N 2017/25.17.

89 Zie bijv. P.G.M. Jansen, Beginselen van behoorlijk bestuur in het belastingrecht, Den Haag: Sdu Uitgevers 2013, p. 107-114.

90 Bijv. HR 24 september 2010, ECLI:NL:PHR:2010:BM1206, BNB 2010/314. 
- waarbij de fiscale gevolgen van vertaalfouten in de regel voor rekening van burgers komen - aan herijking toe is. ${ }^{91}$ Argumenten daarvoor zijn bijvoorbeeld:

1 De 'voorlichtingsjurisprudentie' van de Hoge Raad dateert van zo'n veertig jaar geleden, terwijl de wereld op het punt van voorlichting ingrijpend is veranderd (denk aan de opkomst van internet, wat bijvoorbeeld de hoeveelheid en toegankelijkheid van voorlichting sterk heeft vergroot).

2 Het belastingrecht grijpt eenzijdig in de financiële positie van burgers in. De meeste burgers lezen geen (belasting)wetten - en zelfs als zij dat wel zouden doen, is maar de vraag of zij het daarmee 'beter' zouden (kunnen) weten dan de Belastingdienst.

3 Veel burgers zullen niet bekend zijn met het gebrek aan juridische status van voorlichting. Dat is vanuit een burgerperspectief, gezien bijvoorbeeld het gebrek aan (gerichte) disclaimers, verklaarbaar.

Kortom, is het nog wel terecht dat vertaalrisico's in beginsel bij burgers worden gelegd, terwijl zij part noch deel hebben aan de vertaalslag? ${ }^{92}$

\section{De belastingwetgever en naar begrijpelijke taal vertaalde belastingwetgeving}

Gezien het belang van begrijpelijke vertalingen voor de uitvoering van belastingwetgeving en hun gebrek aan juridische status, is mijns inziens (ook) een blik op de belastingwetgever gerechtvaardigd: hoe kan deze (beter) voorsorteren op de 'vertaalpraktijk' van de Belastingdienst? ${ }^{93}$ Ondanks het feit dat de omvang van deze bijdrage niet de ruimte biedt om deze vraag diepgaand te bespreken, wil ik gezien het onderwerp van dit themanummer desalniettemin een aanzet doen. Ik zie twee sporen voor de wijze waarop de wetgever zich (beter) rekenschap zou kunnen geven van de vertaalslag die inherent in de uitvoeringssfeer plaatsvindt: (1) met goede wetgeving bijdragen aan het (zo veel mogelijk) voorkomen van 'vertaalfouten', en (2) bijdragen aan rechtsbescherming van burgers. Ik ga op beide aspecten kort in.

\subsection{Voorsorteren door wetgever op voorkomen 'vertaalfouten'?}

Welke rol kan de wetgever spelen bij het (zo veel mogelijk) voorkomen van vertaalfouten in de uitvoeringssfeer? In de eerste plaats - vanzelfsprekend met kwalitatief goede (duidelijke, eenvoudige, toegankelijke enzovoort ${ }^{94}$ )

91 Zie Cramwinckel 2014, par. 5.

92 Deze vraag staat centraal in mijn lopende promotieonderzoek.

93 Vgl. J.L.M. Gribnau, A.O. Lubbers \& H. Vording, 'Verbetering van de kwaliteit van (de uitvoering van) fiscale regelgeving door terugkoppeling', WFR 2009/675: 'De wetgever ontwerpt fiscale regels (...). Vervolgens kan er van alles misgaan: de regels zijn onduidelijk, de uitvoering verloopt rommelig, de burger komt onbedoeld in moeilijkheden. In zulke gevallen dient de wetgever vast te stellen dat hij zijn werk niet goed genoeg heeft gedaan, en lering te trekken uit de geconstateerde gebreken.'

94 Zie Van den Heuvel 2018. 
belastingwetgeving. ${ }^{95}$ Enerzijds kan de wetgever bij de voorbereiding van wetgeving rekening houden met de uitvoering (zie ook de bijdrage van Wolferink e.a. in dit themanummer). ${ }^{96}$ Anderzijds kan de wetgever tot stand gekomen wetgeving zo nodig aanpassen (verbeteren) met het oog op de uitvoering.

Het veronderstelde verband tussen kwalitatief goede wetgeving en goed uitvoerbare wetgeving ${ }^{97}$ impliceert dat de wetgever lessen zou kunnen trekken uit de wijze waarop wetgeving wordt uitgevoerd - en dus ook de wijze waarop deze wordt vertaald. ${ }^{98}$ Het theoretische concept dat zich hierbij onmiddellijk opdringt, is dat van 'terugkoppeling'. Bij terugkoppeling in het belastingrecht gaat het volgens Gribnau, Lubbers en Vording om het proces waarbij signalen met betrekking tot onvolkomenheden in fiscale regelgeving worden 'teruggesluisd' naar de fiscale regelgever. ${ }^{99}$ Een belangrijke bron van dergelijke signalen is afkomstig van de rechter, zoals het themanummer van RegelMaat over terugkoppeling uit 2018 laat zien. ${ }^{100}$ Signalen kunnen uiteraard ook afkomstig zijn van andere bronnen, zoals de Nationale ombudsman of wetsevaluaties.

Mijns inziens kunnen ook vertalingen van de Belastingdienst - zoals voorlichting - worden gebruikt voor terugkoppeling van signalen met betrekking tot onvolkomenheden in de belastingwet aan de belastingwetgever. Deze invalshoek is bij mijn weten in de (nationale) fiscale literatuur nog niet eerder onderzocht. Een methode kan worden ontleend aan de bijdrage van de Amerikaanse wetenschapper Monroe, die heeft betoogd dat publicaties van de Amerikaanse belastingdienst (IRS) een belangrijke rol kunnen spelen bij vereenvoudiging van belastingwetgeving. ${ }^{101}$ In deze zogenaamde 'IRS publications' wordt het Amerikaanse belastingrecht op toegankelijke en adequate wijze aan het publiek uitgelegd (net zoals in voorlichting van de Belastingdienst).

Monroe's voorstel is, samengevat, dat experts (zoals fiscale wetenschappers) beoordelen in hoeverre de belastingadministratie erin is geslaagd een 'goede'102

95 Complexe wetgeving leidt ertoe dat de Belastingdienst 'veel inspanningen' moet verrichten bij zijn uitvoeringstaak, bijv. in brief Staatssecretaris van Financiën 3 april 2018, kenmerk 2018-0000039871, p. 2.

96 Illustratief is de uitvoeringstoets bij belastingwetgeving, bijv. bij het Belastingplan 2019 (zie bijlage bij Kamerstukken II 2017/18, 31066, nr. 421). 'De interactie met burgers en bedrijven is een vast onderdeel van de uitvoeringstoetsen van de Belastingdienst', aldus het kabinet in Kamerstukken II 2018/19, 35026, nr. 4, p. 7.

97 Voor het verbeteren van de kwaliteit van wetgeving zijn signalen uit de praktijk een onmisbare bron van informatie, zo betogen Gribnau, Lubbers \& Vording 2009.

98 Vgl. brief Staatssecretaris van Financiën 19 mei 2014, kenmerk DGB/2014/2920 U, p. 5 en bijlage: 'Vereenvoudigingen in het fiscale beleid maken het ook mogelijk te komen tot meer eenduidige interactie en duidelijkere communicatie met de burger.'

99 Zie J.L.M. Gribnau, A.O. Lubbers \& H. Vording (red.), Terugkoppeling in het belastingrecht, Amersfoort: Sdu Uitgevers 2008. Zij bouwen voort op o.a. de bundel Terugkoppelen naar de wetgever, Den Haag: Raad van State 2006.

100 Themanummer 'Terugkoppeling door de rechter aan de wetgever', RegelMaat 2018, afl. 6.

101 A. Monroe, 'Hidden in Plain Sight: IRS Publications and a New Path to Tax Reform', Florida Tax Review (21) 2017, afl. 1, p. 81-147.

102 Monroe 2017, p. 86 en 119. 
uitleg van een wettelijke regeling te geven. Waar dat niet het geval is, is mogelijk sprake van een te hoge mate van complexiteit in de onderliggende wet. ${ }^{103}$ Het geconstateerde vertaalprobleem functioneert als een 'red flag', en dan is nader onderzoek op zijn plaats. ${ }^{104} \mathrm{Als}$ experts verbeteringen in de wetsuitleg kunnen aanbrengen, is dat een aanwijzing dat tekortkomingen niet per se door de wetgever worden veroorzaakt. Als de experts er daarentegen niet in slagen een betere uitleg te geven dan de belastingadministratie, vormt dat een serieuze aanwijzing dat sprake is van een (complexiteits)probleem in de wet. De voorgestelde methode kan volgens Monroe worden ingezet om (1) problematische gevallen van complexiteit in belastingwetgeving te identificeren, (2) hierin prioriteit aan te brengen, en (3) aldus systematische vooruitgang te boeken bij de vereenvoudiging van belastingwetgeving. ${ }^{105}$

Interessant aan de door Monroe voorgestelde methode is dat zij daarbij impliciet leunt op de assumptie dat als een wet niet goed is vertaald, er potentieel ${ }^{106}$ iets mis is met die wet. Oftewel, aan een vertaalfout ligt mogelijk een probleem in de wet ten grondslag (de regeling is bijvoorbeeld te ingewikkeld, onduidelijk of voor meerderlei uitleg vatbaar). Geconstateerde vertaalfouten - bijvoorbeeld door experts of in de rechtspraak - zijn dan ook potentieel waardevolle signalen voor de wetgever met het oog op de verbetering van de kwaliteit van wetgeving. Mijns inziens zou de belastingwetgever dergelijke signalen kunnen gebruiken én serieus moeten nemen, want wanneer wetgeving door de Belastingdienst 'niet uit te leggen blijkt, is het misschien een goed idee deze aan te passen'. ${ }^{107}$ De methode van Monroe kan hierbij als uitgangspunt dienen. Dit idee verdient mijns inziens nadere uitwerking (bijvoorbeeld in de vorm van een samenwerking tussen wetgevingsexperts en voorlichtingsexperts).

\subsection{Rechtsbescherming door wetgever bij 'vertaalfouten'?}

De hierboven besproken route komt er in de kern op neer dat de belastingwetgever de Belastingdienst met goede (duidelijke, niet te complexe, enzovoort) belastingwetgeving helpt om goede vertalingen te kunnen maken. ${ }^{108}$ Vervolgens rijst de vraag of de belastingwetgever ook iets (meer) zou kunnen betekenen voor burgers die vertrouwen ontlenen aan (al dan niet gebrekkig) vertaalde belastingwetgeving. Die rol is in het huidige kader met name weggelegd voor de belastingrech-

103 Vgl. Monroe 2017, p. 119: 'Where the IRS fails to explain substantive tax law to non-expert stakeholders simply and accurately, the failed explanation itself acts as a red flag, signaling the potential for a consequential complexity problem in the underlying law.'

104 Uitgebreider: Monroe 2017, p. 118-125.

105 Vgl. Monroe 2017, p. 118-119.

106 Potentieel, want een vertaalfout kan uiteraard ook worden veroorzaakt door andere zaken (onvoldoende capaciteit op uitvoeringsniveau, een menselijke fout, enz.).

107 Zie M.H. Ippel, 'De mens als maatstaf voor de regels van het algemeen bestuursrecht', NTB 2018/63, par. 7.1 .

108 Uit een eerdere casestudy in Cramwinckel 2014 volgt dat een relatief eenvoudige regeling (zoals de aldaar behandelde alleenstaande-ouderkorting uit de inkomstenbelasting) zich gemakkelijker laat vertalen dan een relatief complexe regeling (zoals de integratieheffing in de omzetbelasting). 
ter, maar hoeft uiteraard niet aan hem te zijn voorbehouden. Enkele suggesties op wetgevingsniveau zijn:

1 Codificatie van het vertrouwensbeginsel. Hoewel codificatie geen panacee is (en de formulering ook niet gemakkelijk zal zijn), ${ }^{109}$ is het (a) een goede impuls om de reikwijdte van dit beginsel te doordenken en (b) een belangrijk signaal dat (ook) de wetgever oog heeft voor het feit dat de Belastingdienst bij de uitvoering (inclusief vertaling) van wetgeving verwachtingen kan wekken.

2 Wettelijk vastleggen van de voorlichtende taak van de Belastingdienst ('codificatie'). Door niet alleen in de rechtspraak of in beleid, maar ook in wetgeving op te nemen dat de Belastingdienst voorlichting geeft én moet geven aan belastingplichtigen, krijgt deze taak letterlijk juridische status. Dat hoeft mijns inziens overigens niet direct te betekenen dat voorlichting ook zonder meer juridische status krijgt. Wel kan een wettelijke basis - net zoals bij de beleidsvormende taak van de Belastingdienst ${ }^{110}$ - leiden tot (a) doordenking van deze taak, (b) verduidelijking van de hierbij geldende rechten en plichten en (c) mogelijk meer rechtsbescherming.

3 Codificatie van een norm voor goede (zorgvuldige, juiste, duidelijke, enzovoort) communicatie - zoals voorlichting - met burgers. ${ }^{111}$ Ook hier geldt dat codificatie geen wondermiddel is, maar wel (a) dwingt tot doordenking van de aan voorlichting te stellen eisen en (b) daarmee kan bijdragen aan rechtsbescherming.

Uiteraard roepen deze suggesties fundamentele en praktische vragen op die verdere uitwerking verdienen. ${ }^{112}$ Het gaat mij in het kader van deze bijdrage echter vooral om het belang het debat te gaan voeren over de vraag of (ook), en op welke wijze, de wetgever zich beter rekenschap kan geven van de vertaalpraktijk in de uitvoeringssfeer en de onvermijdelijke rechtsbeschermingsvraagstukken die zich hierbij aandienen.

109 Vgl. voorstel Raad van State om het vertrouwensbeginsel te codificeren vanwege het belang voor belastingplichtigen (zie Kamerstukken II 2005/06, 30322, nr. 5, p. 6-7 en nr. 7, p. 29-30). In de literatuur bijv. T. Kortmann, 'Codificatie van het vertrouwensbeginsel', in: T. Barkhuysen e.a. (red.), 25 jaar Awb in eenheid en verscheidenheid, Deventer: Wolters Kluwer 2019, p. 683-693 (en genoemde literatuur); N. de Vos, Europeanisering van het vertrouwensbeginsel, Den Haag: Boom Juridische uitgevers 2011, p. 246-247; J.L.M. Gribnau, 'Behoorlijke belastingheffing. Over fiscale beginselen van behoorlijk bestuur', TFB 2000, afl. 6, p. 16-22.

110 Zie titel 4.3 van de Awb, in het bijzonder art. 4:81 en 4:84 Awb.

111 Het (gecodificeerde) zorgvuldigheidsbeginsel uit afd. 3.2 Awb (zorgvuldigheid en belangenafweging) heeft betrekking op de voorbereiding van een besluit (art. 3:2 Awb) en een zorgvuldige belangenafwezig (art. 3:4 Awb). In de fiscale literatuur wordt dit niet standaard in verband gebracht met goede voorlichting (zie bijv. Jansen 2013).

112 Wat betekent dit bijvoorbeeld voor de status van vertalingen afkomstig van de uitvoerder ten opzichte van wetgeving afkomstig van de democratisch gelegitimeerde wetgever? Wat is de reikwijdte van een dergelijke zorgvuldigheidsnorm, de mate van bescherming van een gecodificeerd vertrouwensbeginsel, en wat zijn de consequenties van een wettelijk verankerde voorlichtende taak? 


\section{Afronding}

In deze bijdrage heb ik aandacht besteed aan de vertaalslag die de Belastingdienst maakt van complexe fiscale wetgeving naar begrijpelijke taal in de vorm van voorlichting aan burgers. Wanneer met voorlichting 'voorbij juridisch taalgebruik wordt gegaan', rijzen vragen van praktische aard (bijvoorbeeld hoe wordt de vertaalslag gemaakt?), maar ook van juridische aard (bijvoorbeeld wat zijn de consequenties van de vertaalslag, en wat is de juridische waarde van een vertaling?). De antwoorden op genoemde vragen zijn besproken in de context van het belastingrecht, maar de vertaalproblematiek speelt ongetwijfeld ook binnen andere (rechts)gebieden (met name als het bijvoorbeeld gaat om terreinen waarmee veel burgers in aanraking komen, die complex van aard zijn en die aan burgers administratieve verplichtingen opleggen). In zoverre kan deze thematiek dus in breder opzicht interessant zijn.

De Belastingdienst blijkt een early adopter als het gaat om begrijpelijk taalgebruik, waarbij voorlichting een belangrijk instrument is in de uitvoeringsstrategie. Hoewel begrijpelijke wetsuitleg evident voordelen heeft voor zowel de Belastingdienst als burgers, heeft die ook een keerzijde. De nadelen blijken vooral problematisch als burgers onvoldoende rechtsbescherming hebben bij vertaalfouten. Dit alles betekent overigens niet dat de Belastingdienst terughoudend moet (of wil) zijn met vertalen, integendeel. Wel dwingt het tot nadenken over de vraag hoe enerzijds de voordelen voor burgers en de Belastingdienst kunnen worden geoptimaliseerd, terwijl anderzijds de nadelen worden beperkt. Tot slot heb ik aandacht besteed aan de rol van de belastingwetgever en de vraag gesteld of, en zo ja hoe, de belastingwetgever (beter) zou kunnen voorsorteren op de 'vertaalpraktijk'. Als suggesties denk ik enerzijds - uiteraard - aan kwalitatief goede belastingwetgeving en anderzijds aan het bieden van (meer) rechtsbescherming in gevallen waarin zaken 'lost in translation' raken, zoals soms onvermijdelijk is. Een idee is bovendien dat geconstateerde 'vertaalfouten' kunnen worden gebruikt als signalen voor potentieel problematische belastingwetgeving ('terugkoppeling'). Deze suggesties verdienen verdere uitwerking.

$\mathrm{Al}$ met al illustreert deze bijdrage dat begrijpelijk taalgebruik weliswaar 'normaal' is, maar juristen voor boeiende vraagstukken stelt, waarbij burgers niet uit het oog mogen worden verloren. 